IZA DP No. 5235

Is Social Security Secure with NDC?

Tito Boeri

Vincenzo Galasso

October 2010 


\title{
Is Social Security Secure with NDC?
}

\author{
Tito Boeri \\ IGIER, fRB, Università Bocconi, \\ CEPR and IZA \\ Vincenzo Galasso \\ Dondena, IGIER, \\ Università Bocconi and CEPR
}

\section{Discussion Paper No. 5235 \\ October 2010}

\author{
IZA \\ P.O. Box 7240 \\ 53072 Bonn \\ Germany \\ Phone: +49-228-3894-0 \\ Fax: +49-228-3894-180 \\ E-mail: iza@iza.org
}

Any opinions expressed here are those of the author(s) and not those of IZA. Research published in this series may include views on policy, but the institute itself takes no institutional policy positions.

The Institute for the Study of Labor (IZA) in Bonn is a local and virtual international research center and a place of communication between science, politics and business. IZA is an independent nonprofit organization supported by Deutsche Post Foundation. The center is associated with the University of Bonn and offers a stimulating research environment through its international network, workshops and conferences, data service, project support, research visits and doctoral program. IZA engages in (i) original and internationally competitive research in all fields of labor economics, (ii) development of policy concepts, and (iii) dissemination of research results and concepts to the interested public.

IZA Discussion Papers often represent preliminary work and are circulated to encourage discussion. Citation of such a paper should account for its provisional character. A revised version may be available directly from the author. 
IZA Discussion Paper No. 5235

October 2010

\section{ABSTRACT}

\section{Is Social Security Secure with NDC?*}

The introduction of NDC public pension scheme in few European countries, such as Latvia, Sweden, Italy, and Poland, in the nineties was motivated, among other things, by the need (i) to ensure the long term financial sustainability of the public pension system by linking pension returns to economic growth; (ii) to reduce the existing distortions in the labor market, due to the existing strong incentives to retire early, (iii) to increase the intergenerational equity of the system, jeopardized by the different returns across generations; and (iv) to reduce the systematic political interference with public pension systems under aging through the introduction of a sequence of automatic adjustments in the system that do not require government intervention. After more than ten years from their introduction, these systems have performed reasonably well on these accounts. However, some degree of political involvement with the working of the pension systems has continued (f.e., in Italy), and new concerns have emerged. In particular, the combination of a pension system, which strongly bases the benefit calculation on previous contributions (and on thus labor market status), and the existence in some countries of a dual labor market, with young workers being held on the margin of the regular labor market for many years, create a new, potentially strong challenge to these systems. Our simulations of the future pension benefits for the current generation of young workers with a discontinuous working history in Italy and Sweden suggest that the replacement rates will be low, unless the retirement age is significantly increased. This effect may end up jeopardizing the political sustainability of these NDC systems in the future, unless important labor market reforms are introduced. We discuss the effects on the future generation of retirees in Italy and Sweden of a current labor market reform: the introduction of a unique labor market contract, aimed at reducing the dualism between temporary and permanent workers.

JEL Classification: J26, J68

Keywords: notional defined contribution, pay as you go, labor market dualism and pensions

Corresponding author:

Tito Boeri

Department of Economics

Università Bocconi

via Roentgen 1

20136 Milano

Italy

E-mail: tito.boeri@unibocconi.it

\footnotetext{
* We thank participants at the NDC Conference in Stockholm for useful comments and Massimo Anelli for skilful research assistance. All remaining errors are ours.
} 


\section{Introduction}

The ongoing process of population aging has so far required several adjustments in the public PAYG social security systems around the world. And more reforms will follow. In 2000, individuals aged 65 years or more represented $14 \%$ of the population in the industrialized world (Europe, North America, Australia, New Zealand, and Japan), up from 8\% in 1950. Yet, the proportion of elderly is expected to reach $26 \%$ by the year 2050. Public pension spending has increased accordingly. In 2007, the average ratio of pension spending to GDP was $10.2 \%$.

To cope with the financial sustainability of the public pension systems, international institutions, academic and policy-makers have largely endorsed a multi-pillar system based on the existence of a public first pillar (in some instances to be small and highly redistributive), a mandatory private second pillar, and a voluntary private third pillar (see World Bank, 1994). ${ }^{2}$ This view has been farreaching: several non-OECD countries - mainly in Latin America - have chosen to follow this route. But also many European countries have recently reformed their pension systems broadly in this direction (Table 1). The initial, main reform aimed at reducing public intervention in the pension provision was perhaps the 1986 Social Security Act in the UK, which favored the “contracting-out” from the public system ${ }^{3}$ into defined contribution (DC) occupational plans or into the newly introduced personal pension plans. In the next decade, several countries followed. There were also reforms undoing previous reforms that had reduced public pension outlays. This is a clear indication of the political economy obstacles to pension reforms.

Table 1. Pension reforms in Europe (15 countries), 1986-2005

\begin{tabular}{lrrrrr}
\hline & $1986-90$ & $1991-95$ & $1996-00$ & $2001-05$ & Total per row \\
Increasing generosity & 12 & 9 & 16 & 16 & 53 \\
Decreasing generosity & 13 & 26 & 29 & 28 & 96 \\
Total per column & 25 & 35 & 45 & 44 & 149 \\
\hline
\end{tabular}

Source: fRDB-IZA Social Reforms Database (available at www.frdb.org)

The most innovative reforms took place in Latvia, Italy, Poland, and Sweden, with the introduction of notional defined contribution (NDC) systems. For instance, in 1995, in Italy the Dini reforms transformed the public pension system into a notional defined contribution (NDC) scheme, and contemporaneously introduced fiscal incentives for voluntary private pension schemes, which were

\footnotetext{
${ }^{2}$ A recent critical appraisal of this World Bank view is in Barr and Diamond (2008).

${ }^{3}$ The contracting-out option was already presented since the Social Security Pension Act in 1975.
} 
then strengthened in 2004 and again in 2007. In Sweden, the blueprint of the reform to switch to a notional defined contribution (NDC) scheme was produced in 1992 by the Parliamentary Working Group of Pension. The actual reform was approved by the Parliament in 1994 and its implementation began the following year. The switch to a NDC scheme in the public pension system was accompanied by the introduction of a small mandatory defined contribution (DC) pension scheme, and of (quasi-mandatory) occupational plans, which were intended to compensate the reduction in the generosity of the public pensions. The latest European country to adopt an NDC system was Poland in 1999. As in the case of Italy, the scheme entirely replaced the previous public pension system, but along a lengthy transition process, since only individuals under the age of 50 were affected. On the contrary, the Latvian NDC scheme was introduced on January $1^{\text {st }} 1996$ and was immediately effective for all workers. Other countries where NDC public pension schemes were introduced include Mongolia and the Kyrgyz Republic.

The basic idea behind a Notional Defined Contribution (NDC) system is to bring a PAYG system, in which (defined) contributions from current workers finance pensions to current retirees, to mimic a financial account scheme in which workers contribute during their working life and draw (defined) benefits after retiring. Unlike financial account schemes, however, contributions to a NDC system are not invested in financial assets, and hence the returns on these contributions do not depend on stock market or bond returns. The system is notional in that contributions flow to the national social security administration, which uses them to cover current pension benefits. The returns on these defined contributions are exogenously set, and typically coincide with some long term average of the per-capita growth rate of the GDP or of the wages. Once a worker retires, the total capitalized value of his/her life-time contributions is transformed into a (typically) real annuity: the pension benefit. As discussed in details in section 3, this annuity may depend, among other things, on the average life expectancy and on the retirement age.

The introduction of these NDC public pension schemes was motivated, among other things, by the need to (i) to ensure the long term financial sustainability of the public pension system by indexing pension returns to economic growth; (ii) to reduce the existing distortions in the labor market, due to the existing strong incentives to retire early, (iii) to increase the intergenerational equity of the system, jeopardized by the different returns across generations; and (iv) to reduce the systematic political interference with public pension systems under aging through the introduction of a sequence of automatic adjustments in the system that do not require government intervention. 
In fact, despite remaining a PAYG system, the NDC schemes have been used to curb the raise in pension spending by indexing its increase to the growth rate of the economy. The defined contribution feature of these systems has also been exploited to reduce the pre-existing labor market distortions, since additional years of contributions now translate into higher pension benefits. This property of NDCs is strengthened by the adoption of transformation coefficients for the conversion of the capitalized contributions into a flow of pension benefits that depend on the retirement age. NDC systems have also been prized for their supposed higher intergenerational equity, as well as for their high degree of insulation from political influence, since most adjustments to their calculation coefficients (such as the returns on contributions, and the transformation coefficients) can automatically be determined from GDP data and mortality tables.

In brief, NDC schemes have often been proposed as - at least part of - the structural response to the ongoing challenges to the public pension systems, such as aging, the growing distortions in the labor market, the need to diversify retirement income - particularly in periods of low growth and stock market crash, the quest for intergenerational (actuarial) fairness and long-term financial sustainability. To some degree, NDCs appear to be the new Conventional Wisdom in pension systems. And this perception is further justified by that fact that also Germany recently adopted some features in its (point) pension system that mimic some of the NDC key principles (see BoershSupan and Wilke, 2006), and even in France there is discussion about moving in this direction (see Legros, 2006; and Holtzman and Palmer, 2005).

After more than ten years from their introduction, we are now in a position to judge the actual effectiveness of these systems to perform all the difficult tasks described above. Indeed, on many of these desiderata, these NDC systems performed reasonably well. Auerbach \& Lee (2009) provide a positive assessment of their risk sharing properties (in particular in the case of Sweden), although they highlight their costs in terms of low returns on contributions. Retirement age steadily increased in the countries that adopted these systems, indeed, as well as in other countries. And most international institutions share a rather positive assessment on the future financial sustainability of these systems. NDCs are considered to have better properties than non-NDC PAYG systems even when these comparisons are carried out across an homogeneous set of countries, as clearly shown in the next figure, taken from a 2009 European Commission report. 
Figure 1: Change in the Public Pension/GDP over 2007-

60

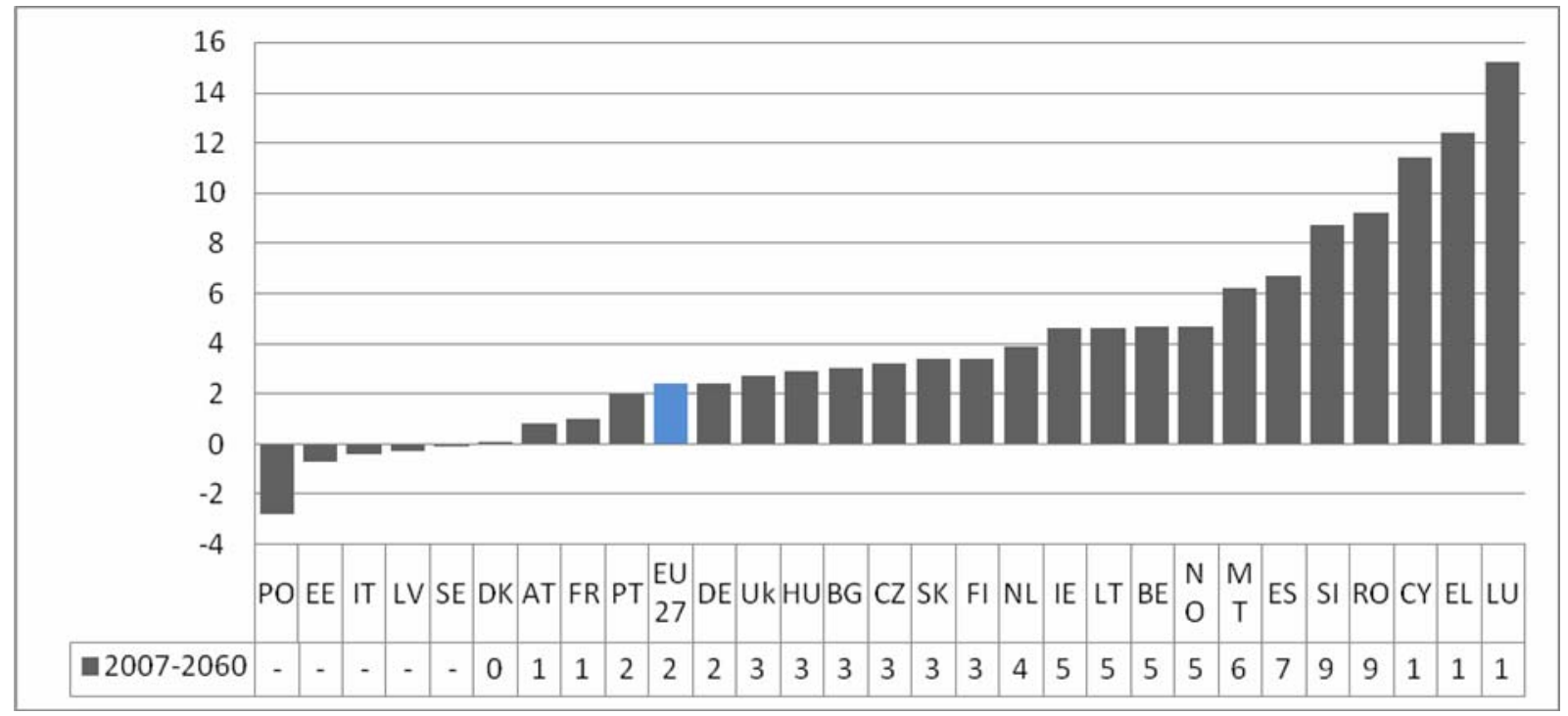

However, in some countries, notably Italy, a large degree of political involvement with the working of the pension systems has remained. After the 1995 Dini reform, which introduced the NDC system for private workers, and the Prodi reform in 1997, which extended it to the public sector workers, few other reforms have been passed that modified the original, flexible, yet (almost) actuarially fair, retirement age, undermining the fundamentals of an NDC system. While the increase in the retirement age introduced by some of these reforms may present an element of continuity with the previous reforms, the reduction in the flexibility of the retirement system and in its reliance on incentives to induce later retirement represents a break with the philosophy of the NDC scheme. Moreover, the revision of the conversion coefficient that was due in 2005 to account for the increase in the survival probability, and was under the responsibility of the Minister of Economics, was repeatedly postponed.

The main contribution of this paper is to analyze the interactions between NDC systems, as those introduced in Italy and Sweden, and the recent developments in the labor market of these two countries. Our major concern is that the combination of a pension system, explicitly linking pension benefits on lifetime contributions (hence labor market status), and the existence in some countries of a dual labor market, with young workers being held on the margin of the regular labor market for many years, create a new, potentially strong challenge to these pension systems. The current generation of young workers will approach retirement age with limited pension rights. Besides requiring a large increase in the retirement age, this dualism may jeopardize the political 
sustainability of these NDC systems in the future, unless important labor market reforms are introduced. We simulate the effect of this labor market situation on the future pension benefits of current young workers in Italy and Sweden, and discuss the effects on future pensions of a labor market reform: the introduction of a unique labor market contract, aimed at reducing the dualism between temporary and permanent workers.

The paper proceeds as follows. The next section will discuss the political sustainability of PAYG pension systems under aging, and will address some specific concerns that arose after the introduction of the NDC systems in Italy and Sweden. Section 3 describes the pensions systems and labor market dynamics and their interactions in Italy and Sweden. Section 4 presents a simple simulation of the pension benefits that current young cohorts of workers may expect to receive under different pension systems and different labor market structures in Italy and Sweden. Finally, section 5 discusses the future of NDC systems and concludes.

\section{What are the future challenges?}

Over the last three decades, the major challenge to pension systems has been commonly viewed to come from population aging. The widespread drop in the fertility rate, and the contemporaneous increase in longevity have led to a raise in the share of elderly individuals, who retire to obtain a pension benefits, and to a reduction in the share of individuals in working age, which poses serious concern for the financial sustainability of any PAYG pension system, including NDC schemes. If pension benefits' calculations were to remain unchanged in the future, the contribution rates used to finance the systems should necessarily increase. Alternatively, if contribution rates were to remain constant, other reform measures ought to be adopted, such as an increase of the retirement age, a reduction of the pension benefits, or a switch in the pension indexation from wages to prices, as already implemented in many countries.

However, aging has economic, as well as political effects. To fix ideas, consider the pension system as a - potentially redistributive - saving device, which allows individuals to "save" in their working years through social security contributions, and to receive the returns from their "savings" in old age, as pension benefits. The economic effect of aging is given by the increase in the ratio of retirees to workers - the old age dependency ratio. Since the average long run return of a PAYG pension system depends on this old age dependency ratio and on the growth rate of productivity, 
aging reduces the average long-term profitability of the system. As in any portfolio decision, agents expecting lower returns from their assets should be induced to substitute their claims towards future pensions with more private savings. Therefore, the economic effect of aging should induce a reduction in the size of the pension system, since this has become less convenient.

However, as population ages, so does the electorate - and other relevant political players, such as the union's members. The aging process thus leads to an increase in the political representation of the elderly - to the appearance of the "gray panthers", who gather a larger share of votes. Politicians seeking re-election will clearly be keen on addressing the needs of this crucial voting group - the elderly - with generous welfare policies. Aging will thus have a political effect, consisting in an increase of the relevance of pension spending on the political agenda ${ }^{4}$. A synthetic measure of the political effect of aging is given by the median age among the voters. According to Galasso (2006), in 2000, the median age among the voters in a sample of OECD countries ranged between 44 years in Spain and 47 years in France and the US. The evolution over time of the median age among voters shows a striking expected increase. In 2050, the median age will vary between 53 years - in the UK and the US - and 57 years in Spain. Unsurprisingly, Spain and Italy, which undergo the most dramatic aging process will, also face the largest change in the median age, respectively 13 and 11 years.

Concerns about the future financial consequences of the aging process, as well as the short-term financial solvency of the pension system led to a sequence of pension reforms in Italy in the early 90s, which included the introduction of a NDC system in 1995. Similar reforms took place in many other European countries, such as France and Germany (see Holtzman and Palmer, 2006). Yet, these policy responses to the aging process risk not be conclusive - among other things because the aging process has proven more severe than initially forecasted, due to an underestimation of the increase in longevity. Table 2 reports the actual share of the population aged 65 years or more in several European countries in 1980 and 2007, and their forecast for the year 2020 and 2050 as done in 1988 and in 2009. The current aging process is visible in the differences between the first two

\footnotetext{
${ }^{4}$ It is worth noticing that the political influence of the elderly is magnified by two crucial features. First, their preferences in terms of economic policies are homogenous. In fact, while young and middle-aged individuals typically differ along several dimensions (employment status, economic conditions, family profiles), and may thus have conflicting preferences over many economic policies; elderly individuals (retirees) are "single-minded" (see Mulligan and Sala-i-Martin, 1999): they care mostly about pensions and health care. Second, in several countries, elderly voters tend to have higher turnout rates at elections - defined as the percentage of people who actually vote among those who are entitled to - than the young. Since the aggregate impact of this voting pattern may be sizeable, the aging process may lead to a disproportionate political representation of the elderly.
} 
columns, which show for instance that between 1980 and 2007 the share of the elderly increased from $13.4 \%$ to $19.9 \%$ in Italy, and from $16.3 \%$ to $17.4 \%$ in Sweden. The forecasting errors about the aging process for the years 2020 and 2050 respectively are presented in the fifth and eighth columns. Table 2 shows that in 2009 Italy had to largely modify the previous forecast for the year 2020 , from $19.4 \%$ to $22.7 \%$, as well as for the year 2050 , from $22.6 \%$ to $32.6 \%$. Notice that the Swedish forecast for the year 2020 was not to be revised, while further aging was envisaged for the 2050, from $21.4 \%$ to $24.7 \%$. Large forecasting errors for the year 2050 were also made in Greece, Germany, Portugal and Spain, and may thus lead to additional pressure for reforming pensions.

Table 2: Actual and forecasted share of elderly (65+) in the population

\begin{tabular}{|c|c|c|c|c|c|c|c|c|}
\hline & 1980 & 2007 & $\begin{array}{c}\text { E88 } \\
(2020)\end{array}$ & $\begin{array}{c}\text { E09 } \\
(2020)\end{array}$ & $\begin{array}{c}\text { Delta } \\
\text { E(2020) }\end{array}$ & $\begin{array}{c}\text { E88 } \\
(2050)\end{array}$ & $\begin{array}{c}\text { E09 } \\
(2050)\end{array}$ & $\begin{array}{c}\text { Delta } \\
\text { E(2050) }\end{array}$ \\
\hline AUT & 15,5 & 16,9 & 19,4 & 19,4 & 0 & 21,7 & 28,2 & 6,5 \\
\hline BEL & 14,4 & 17,1 & 17,7 & 19,5 & 1,8 & 20,8 & 25,7 & 4,9 \\
\hline DK & 14,4 & 15,3 & 20,1 & 20,1 & 0 & 23,2 & 24,5 & 1,3 \\
\hline FIN & 12 & 16,5 & 21,7 & 22,4 & 0,7 & 22,7 & 26,1 & 3,4 \\
\hline FRA & 14 & 16,4 & 19,5 & 20,2 & 0,7 & 22,3 & 25,6 & 3,3 \\
\hline GER & 15,5 & 19,8 & 21,7 & 22,8 & 1,1 & 24,5 & 31,7 & 7,2 \\
\hline GRC & 13,1 & 18,6 & 17,8 & 21,1 & 3,3 & 21,1 & 31,5 & 10,4 \\
\hline IRL & 10,7 & 11,1 & 12,6 & 13,3 & 0,7 & 18,9 & 23,7 & 4,8 \\
\hline ITA & 13,4 & 19,9 & 19,4 & 22,7 & 3,3 & 22,6 & 32,6 & 10 \\
\hline NLD & 11,5 & 14,5 & 18,9 & 19,8 & 0,9 & 22,6 & 26,6 & 4 \\
\hline PRT & 10,2 & 17,3 & 15,6 & 20,1 & 4,5 & 20,6 & 30,1 & 9,5 \\
\hline ESP & 10,9 & 16,7 & 17 & 18,8 & 1,8 & 22,9 & 32,1 & 9,2 \\
\hline SWE & 16,3 & 17,4 & 20,8 & 20,8 & 0 & 21,4 & 24,7 & 3,3 \\
\hline UK & 14,9 & 16 & 16,3 & 18,3 & 2 & 18,7 & 23 & 4,3 \\
\hline
\end{tabular}

Aging, and, in the case of Italy, the deep short term financial unbalance of the pension system, were among the reasons that led to the introduction, in some countries, of this new form of pension scheme - the notional defined contribution (NDC) systems. After their initial implementation, however, additional concerns emerged, as the actual working of these new systems came into play.

The lack of intergenerational fairness in the Italian system is related to two factors. The first is the the delay in updating the transformation coefficients, and low frequency at which this adjustment 
occurs, which create large asymmetries across generations depending on whether they retire before or after the adjustment. The second factor, so far more important, is the long transition period, which allows individuals with more than 18 (15) years of contribution at the end of 1995 (1992) to be shielded from the Dini (Amato) reform. These problems became apparent over the years, as a large policy debate took place on these and other aspects of the Dini reform. Analogously, some concerns emerged on the role of the so called "vintage pensions". In fact, since pension benefits are indexed to prices only (after the 1992 Amato reform), individuals retiring in different years receive pension benefits that, in few years time, may largely differ, with the individuals who retired earlier (the early vintage) receiving much lower pensions.

In Sweden, where the NDC pension system was introduced more gradually, concerns have instead emerged on the role of the financial defined contribution (FDC) system, which accompanied the introduction of the NDC scheme. Several studies (see Diamond, 2004) have in fact criticized the design of this FDC system that leaves a large degree of freedom to the individuals in the choice of their pension funds, but entails large administrative costs.

These concerns have increasingly been addressed in a recent strand of the literature (see contributions in Holtzman and Palmer, 2006), and some policy measures have also been adopted to cope with some of these shortcomings. The aim of this paper is instead to shed some light on a new possible source of instability linked to, albeit not necessarily caused by, these NDC schemes, which stems from the current labor market situation of young individuals in some European countries. In a nutshell, since NDC systems provide a tight link between past contributions and future pension benefits, the recent dual labor market may induce a large negative income effect on the future pension benefits of the current young individuals, as this generation may find itself with insufficient contributions - and hence low pensions - to retire. To address this issue, the next section summarizes the working of the Italian and Swedish NDC pension systems; describes the employment situation for the young, and provides some simulations of the pension benefits that current generation of young may expect to receive in the future under these NDC systems.

\section{The Interaction between Pensions Systems and Labor Market}

A Notional Defined Contribution system is a PAYG pension scheme, in which contributions made during the working years are treated as if they were accumulated into a pension fund invested in assets. Contributions are typically proportional to labor earnings (floors and ceilings on 
contributions may apply), but they do not go to an actual fund, and thus do not receive a market return. They are only notionally accounted as if they were deposited in a fund, and the returns on these contributions are determined by law, often being linked to the growth rate of the economy. Upon retirement, individuals who contributed to the system mature pension rights on the pension wealth accumulated over their working year. This pension wealth is then converted into an annuity - the pension benefit - according to a benefit formula. The next equations provide a basic representation of how pension benefits are calculated in an NDC pension system (a more comprehensive discussion of NDC systems is for instance in Palmer, 2006):

$$
\begin{aligned}
& p=\tau \sum_{i=1}^{n} w_{i} \prod_{j=i+1}^{n+1}\left(1+g_{j}^{w}\right) \frac{1}{\gamma} \\
& \gamma=\sum_{i=1}^{m}(1+\delta)^{1-i}
\end{aligned}
$$

where $p$ is the pension benefit, $\tau$ is the contribution rate on the labor earnings $\left(w_{i}\right), n$ is the number of year of contributions, $g$ is the rate of return on the contributions, $\gamma$ is the inverse of the conversion coefficient, $\delta$ is an imputed indexation rate and $m$ is the expected length of retirement.

Equation (1) shows that pension benefits depend on the accumulated pension wealth and on the conversion coefficient. The pension wealth is obtained by accumulating every year pension contributions, $\tau w$, over time, according to a rate of return on contributions g. At retirement, this accumulated contributions are converted into a stream of income (the pension benefits) through the (inverse of the) conversion coefficient, $\gamma$. As shown at equation (2), this coefficient depends on the average expected longevity at retirement, and on an indexation rate, $\delta$, that regulates the returns on the pension benefits. In some NDC systems, such as in Italy and Sweden (see Gronchi and Nisticò, 2006), this indexation rate is front loaded, as retirees obtain the average benefit of the (future) indexation from the beginning of their retirement period. Finally, notice that the age of retirement affects both equations, by modifying the number of working years, $n$, as well as the length of the retirement period, $m$.

These basic, common features of the NDC system have been adopted in slightly different fashion in Italy and Sweden (for a comprehensive comparison of these two pension schemes on these issues, see Gronchi and Nisticò, 2006). The next section discusses some of the more relevant differences. 


\subsection{Pension Systems in Italy and Sweden}

After the 1995 reform, the Swedish pension system rests on three pillars: a public notional defined contribution (NDC) system; a (smaller) mandatory funded defined contribution scheme (FND) and a wide array of (quasi-mandatory) occupational plans, which cover almost the $90 \%$ of the population (for a detailed description, see Palmer, 2000, Konberg, Palmer and Sunden, 2006). The first two schemes are mandatory; individuals contribute 18.5\% of their labor income, of which 16\% goes to the NDC system, while the remaining $2.5 \%$ is deposited in an individual account. Employees are free to choose their most preferred private fund where to contribute to, and to switch among funds. The default option, in absence of an employee's decision, is the Premium Pension Fund. Funds are privatly managed, but they are regulated by a Premium Pension Authority (PPM), which collects the contributions and negotiates the fee with pensions company. In practice the fund manager has just the PPM as client, which keeps account for all individual participants to the fund ${ }^{5}$ (see Tapia and Yermo, 2007). The quasi mandatory occupational plans stem from the agreements between employers associations and trade unions. The membership is compulsory for all the eligible employees of an employer covered by the collective agreement, irrespective of whether they are trade union member or not. These plans can be defined contribution or defined benefit.

In the Swedish NDC scheme, the rate of return on the contributions, $g$, is set to be equal to the average wage growth rate; while the imputed indexation rate, $\delta$, see eq. 2 , is fixed at $1.6 \%$. However, if the average wage growth rate differs from $1.6 \%$ per year, the pension benefits for that year are modified accordingly, as shown at the following equation:

$$
\begin{aligned}
& \delta=1.6 \% \\
& P_{t+1}=P_{t}\left(1+\pi_{t}\right)\left(1+g_{t}-\delta\right)
\end{aligned}
$$

where $\pi$ is the inflation rate. Hence, for wage growth rates below $1.6 \%$, the pension benefits are to be reduced. This occurrence took place during the 2008-09 world-wide economic crisis, and led to a modification of this pension calculation feature, as the indexation - and thus the possible change in pension benefits - was linked to a five-years moving average of the wage growth rate, rather than to its annual realization.

\footnotetext{
${ }^{5}$ This system permits to have cost-saving for the fund and at the same time make possible for the PPM to negotiate large rebates on the fees, given its market power. Funds just compete by offering the best net return. For this reason Sweden has an overall fee as calculated by Tapia-Yermo lower than $0.50 \%$.
} 
In Italy, the NDC scheme was introduced in 1995, with the Dini reform that completely redesigned the architecture of the Italian social security system. The defined benefit nature of the scheme was abandoned in favor of a notional defined contribution scheme. Seniority pensions were eliminated over a long transition period - and additional norms were introduced to complete the harmonization process across regimes and to provide fiscal incentives for individuals to invest in the private pension funds (for a detailed description, see Franco, 2002, Brugiavini and Galasso, 2004, Gronchi, 1998, and Gronchi and Aprile, 1998).

With the shift to a notionally defined contribution scheme, the Italian social security system remained unfunded - as current retirees' pensions were financed by current workers' contributions - yet, individuals' pension benefits became directly linked to their lifetime contributions to the system. Indeed, this contributive aspect is only figurative: it works as if every worker had a personal fund where her contributions - corresponding to 33\% of her annual earnings - were accrued during her working career. These contributions are capitalized at an interest rate, which is computed as a five years moving average of the nominal GDP growth. At retirement, the accumulated asset value is transformed into an annuity through a conversion coefficient, which depends negatively on the expected longevity at retirement and positively on the retirement age. The imputed indexation rate, $\delta$, at eq. 2 , is fixed at $1.5 \%$. However, unlike in Sweden, even if the average wage growth rate differs from $1.5 \%$ per year, no change is applied to the pension benefits.

The application of this NDC scheme has been pro quota for those workers with less than 18 years of contributions in 1995; while workers with higher seniority remained under the previous regime. The Dini reform has also largely revised the eligibility criteria. Seniority pensions, whose eligibility was exclusively based on reaching a minimum contribution period, were abolished. Under the private employees' scheme, the minimum number of years of contribution to be eligible for a pension was reduced to 5 years only; however, only individuals aged between 57 and 65 years are entitled to a pension. These measures have partially reduced the incentives to retire early, since pension benefits depend on retirement age through an actuarial adjustment factor, which is included in the pension benefit's conversion coefficient.

A first comparison between the Italian and the Swedish NDC pension system can be performed by showing the conversion coefficients, which summarize how the total capitalized pension wealth is converted into a flow of pension benefits. As shown at Figure 2, for a given retirement age, the coefficients are lower in Sweden than in Italy, partially in response to a higher expected longevity at 
retirement among Italian women (21.94 years of expected longevity at age 65 versus 20.88 years for 65 years old Swedish females).

However, Italian pensioners, unlike Swedes, are completely insulated from the underlying labor market conditions. After retiring, pensions are kept constant in real terms, independently of wage growth. This is the source of the "vintage pensions" issue discussed above.

Figure 2: Transformation Coefficients in the Italian and Swedish Pension System

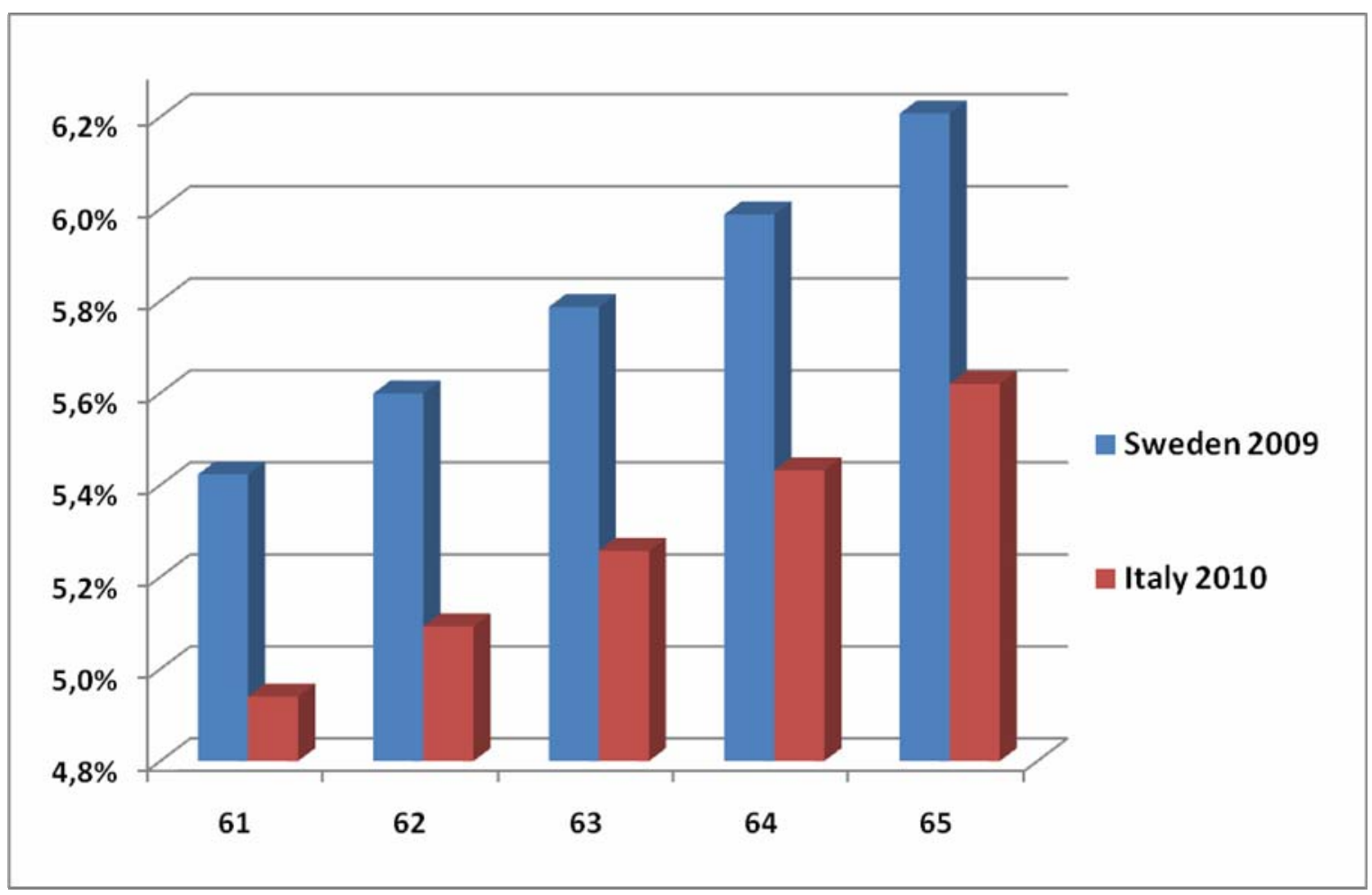

\subsection{Dual Labor Market in Italy and Sweden}

As a result of many asymmetric reforms, introducing flexibility in the labor market only "at the margin”, that is, for new hires, labor markets in countries with strict provisions for regular contracts, like Italy and Sweden, experienced a large increase in the share of fixed-term contracts in total dependent employment rapidly approaching two-digit levels from scratch. Figure 3 provides a graphical representation of this phenomenon by showing the share of temporary workers and the unemployment rate by age group for the young generations in Italy and Sweden.

This dualism also involves a significant wage discount for temporary contracts. This discount is imposed due to the stronger bargaining power of regular workers vis-à-vis workers with flexible 
contracts and to the lower outside option of the latter. It takes into account that, due to eligibility rules to unemployment insurance requiring some minimum contributory record, most workers with flexible contracts do not have access to unemployment benefits in case of job loss. Estimates from micro-data (from the EU-SILC) of the coefficient of a dummy variable capturing permanent contracts, in a (monthly) wage regression carried out over male dependent employment, controlling for education, tenure and the (broad) sector of affiliation, point to a discount of the order of $25 \%$ in Italy and even $40 \%$ in Sweden (where there are unfortunately less observations on temporary employment in EU-SILC, see Boeri, 2010).

Figure 3: Employment by age (2006)

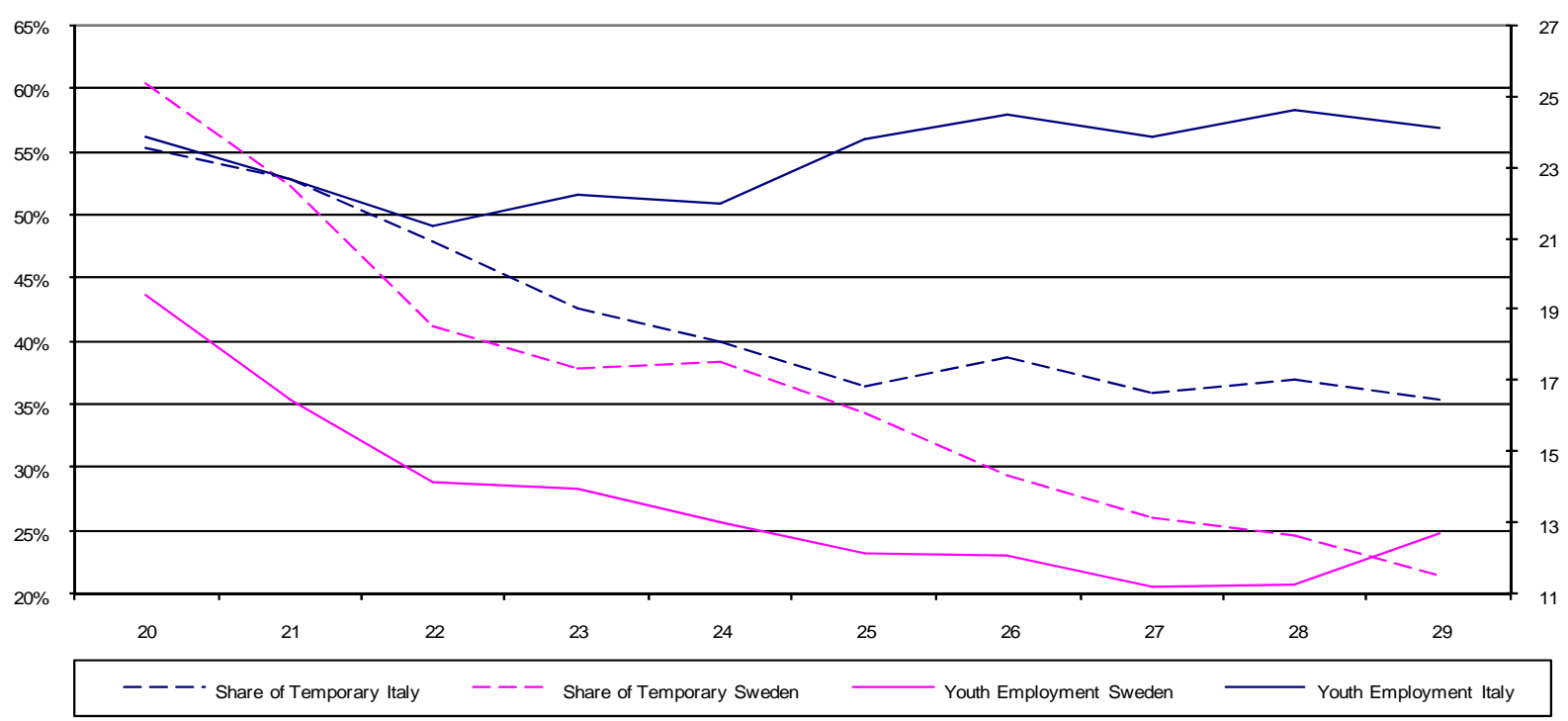

This dualism is likely to deeply affect future pension entitlements of the youngsters. This is because (i) workers with temporary contracts earn, ceteris paribus, less than workers on open-ended contracts; (ii) they experience more frequent career breaks due to the fact that job shedding is concentrated on temporary contracts (as clearly indicated by the Great Recession), and (iii) during unemployment spells, they are generally not covered by unemployment insurance.

This problem of adequacy is directly not related to the design of the NDC itself, but rather to the dualism of labor markets. Thus, solutions should be found by addressing directly this problem and reducing the dualism of labor markets. A politically feasible strategy that has been proposed for France, Italy and Spain (Bentolila, Boeri, and Cahuc, 2010) and could also be tailored to Sweden is to allow for graded employment security. This means that dismissal costs in permanent contracts 
should gradually increase with tenure length. In particular, Governments could promote entrance into the permanent labor market in stages, making job security provisions, in the form of mandated severance payments, increasing steadily as workers acquire tenure without large discontinuities.

To give a few examples, in Italy permanent contract holders are protected from the start by norms forcing employers to reinstate the worker in the firm in case of unfair dismissals, in addition to paying to them a statutory severance pay. In France, when the worker reaches two years in a permanent contract, the employer must provide a personalized plan to help the employee to find another job. In Spain, economic dismissals from permanent contracts require an administrative approval. Employers typically avoid going to Court by paying upfront the worker. These costs can be as high as 36 months of salary in Italy.

A graded tenure scheme could involve in all of these cases a statutory severance payment increasing steadily with tenure length (e.g., 5 days of severance per quarter) up to reaching gradually the maximum level currently envisaged by national regulations. This reduces the uncertainty of firms as to the costs of dismissals, reducing the costs of employment protection for employers. At the same time, it allows flexibility to be preserved without creating a dual labor market structure.

\section{Simulating Future Pension Treatments in Italy and Sweden}

To analyze how the current dualism in the labor market of many European countries may interact with the existence of an NDC pension system, which strongly ties pension benefits to previous contributions, we calculate the expected future pension benefits for two classes of current young individuals in Italy and Sweden. To highlight our concern about the long term effect that discontinuous working careers have on future pension benefits, we consider the situation (case A) of a (male) individual with a career pattern characterized by a sequence of temporary and permanent jobs and unemployment spells. We compare it to (case B) a (male) individual, who enjoys a uninterrupted career with permanent jobs only, but enters the labor market with the same wage as a temporary worker in case $\mathrm{A}$; and to (case $\mathrm{C}$ ) a (male) individual, who also enjoys a uninterrupted career with permanent jobs only, and enters the labor market with an initial wage that is $25 \%$ higher than in the previous cases (see Boeri, 2010). In particular, case A describes the labor market situation of a (male) individual who enters the labor market at age 25 and holds a temporary job until age 28; he then remains unemployed until he turns 29, when he finds a fixed term job, 
which he holds until he is 32, when he becomes unemployed again for one year. At age 33, he obtains a fixed term job, which he holds for two years, until he finally gets a permanent job until retirement. In cases B and C, a (male) individual has instead permanent jobs from his entry in the labor market at age 25 till retirement.

While the former case (A) is more typical of the Italian than of the Swedish labor market, we choose to calculate the expected pension benefits for cases A and B in both countries - and hence systems, in order to be able to compare the results. In both countries, our two representative young individuals will thus have the working careers described above. However, the entry wage will clearly differ between the two countries; individuals will also face different contribution rates $33 \%$ in Italy and 16\% plus an additional 2.5\% in Sweden, and different retirement age - 60, 65 and 67 years in Italy and 65, 67 and 70 in Sweden. Also the expected growth rate of the economy (and of the wages), which was shown in the previous section to be crucial for the pension benefits calculations will differ across countries, being between 1\% and 1.5\% in Italy, and between 1.5\% and $2 \%$ in Sweden. For Italy, where the labor market dualism is more pronounced, we also provide simulations for case C.

\subsection{Simulating the Italian labor market and pension system}

To simulate the effect of the Italian dual labor market on the future pension benefits of the current young generations, we consider three representative young individuals respectively with a discontinuous (case A) and a continuous (cases B and C) working career. We concentrate on male individuals, with upper secondary education. Their wage profile is calculated using European Commission Household Panel data obtained by pooling the 1994-2001 waves. The labor market prospects for our representative young Italian male entering the labor market at age 25 and featuring a discontinuous career are shown at Figure 4. In his initial temporary job, he earns a monthly wage of $€ 800$ (in 2001 prices), which remains relatively constant until age 35, when he obtains a permanent job. At this point, his wage growth becomes steeper, and his monthly wage reaches $€ 1300$ by the end of his working life. 
Figure 4

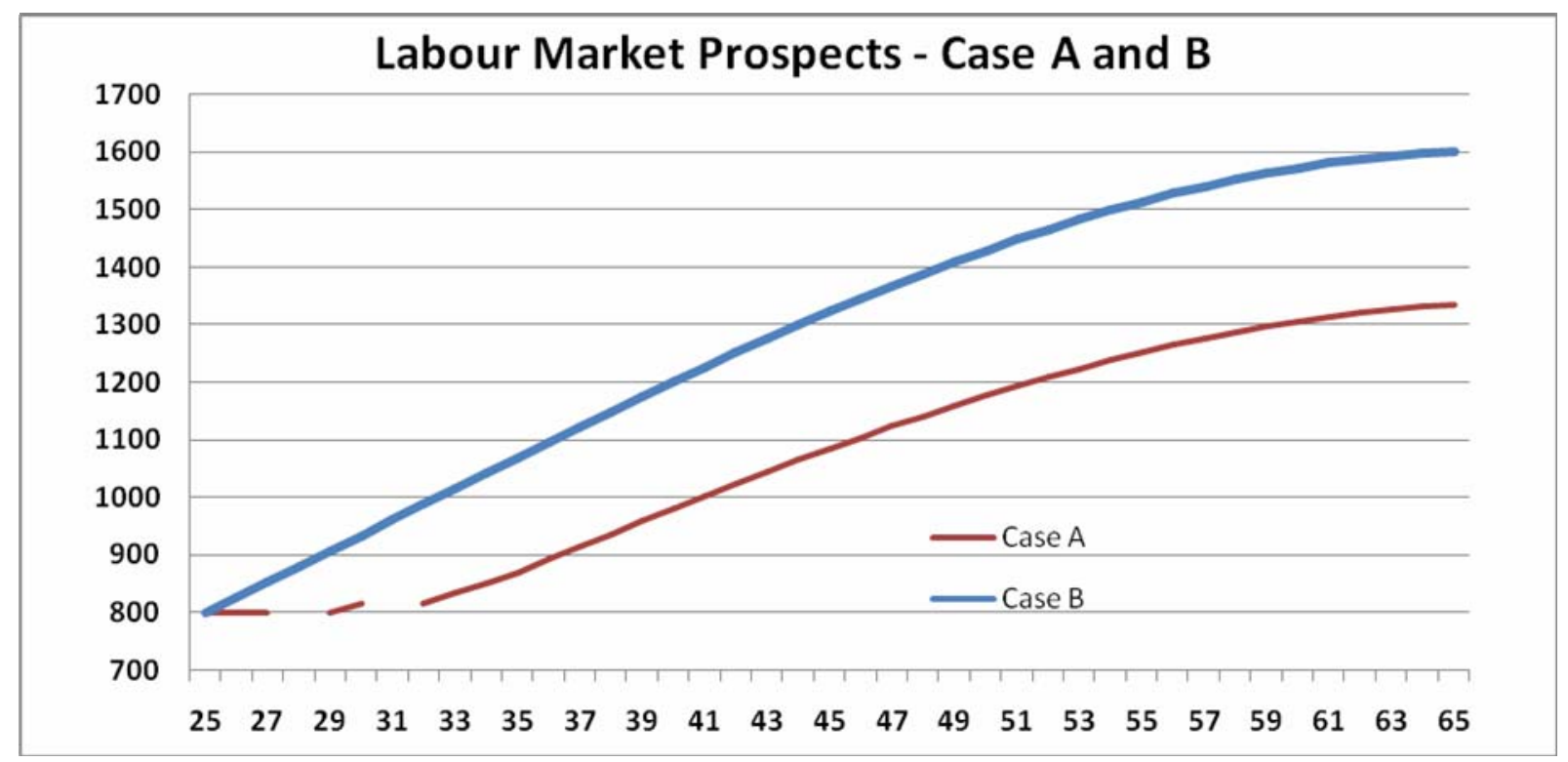

What pension benefit will this individual, who cannot rely on the beneficial compounding capitalization on the very early contributions, due to his discontinuous working career, get? The answer is at Table 3, which provides the monthly pension benefit, and the pension replacement rate (namely, the ratio between the pension benefit and the average wage in the five years prior to retirement) for three different retirement ages (60, 65 and 67 years) and for three (optimistic) projections of the growth rate of the Italian GDP (1\%, 1.2\% and 1.5\%). The results show some variation. If the current representative young individual will retire as early as at 60 years (that is, on average at the same age as his parents), his monthly pension benefit will range between $€ 638$ and $€ 690$, depending on the average growth rate of the economy during his working life, with a replacement rate fluctuating around 50\%. In absence of additional old age resource, such as individual savings or private pension funds, our representative individual will thus be induced by the low pension benefit to postpone retirement (see also the simulation in Galasso, 2008). Retiring at 65 will allow him to reach a pension benefits of $€ 910-996$, depending on the realized economic growth - thereby replacing around $70 \%$ of his wage income. Only when retiring at 67 years, our representative (current) young will be able to obtain a more sizable pension benefit ranging between $€ 953$ and $€ 1052$. 
Table 3: Monthly Pension Benefit

\begin{tabular}{|c|c|c|c|c|c|c|c|c|}
\hline & & & & & & & & \\
\hline & & & \multicolumn{2}{|c|}{ Case A* } & \multicolumn{2}{|c|}{ Case $\mathrm{B}^{* *}$} & \multicolumn{2}{|c|}{ Case $\mathrm{C}^{* * *}$} \\
\hline $\begin{array}{l}\text { Growth } \\
\text { Rate }(g)\end{array}$ & $\begin{array}{l}\text { Retirement } \\
\text { Age }\end{array}$ & $\begin{array}{l}\text { Transformation } \\
\text { Coefficients } \\
\text { (2010) }\end{array}$ & $\begin{array}{l}\text { Monthly } \\
\text { Pension }\end{array}$ & $\begin{array}{l}\text { Replacement } \\
\text { Rate }\end{array}$ & $\begin{array}{l}\text { Monthly } \\
\text { Pension }\end{array}$ & $\begin{array}{l}\text { Replacement } \\
\text { Rate }\end{array}$ & $\begin{array}{l}\text { Monthly } \\
\text { Pension }\end{array}$ & $\begin{array}{l}\text { Replacement } \\
\text { Rate }\end{array}$ \\
\hline \multirow{3}{*}{$1.5 \%$} & 67 & 0.0562 & 1052 & $79 \%$ & 1342 & $84 \%$ & 1677 & $84 \%$ \\
\hline & 65 & 0.0562 & 996 & $75 \%$ & 1273 & $79 \%$ & 1591 & $79 \%$ \\
\hline & 60 & 0.04798 & 690 & $53 \%$ & 889 & $57 \%$ & 1112 & $57 \%$ \\
\hline \multirow{3}{*}{$1.2 \%$} & 67 & 0.0562 & 1015 & $76 \%$ & 1261 & $79 \%$ & 1576 & $79 \%$ \\
\hline & 65 & 0.0562 & 943 & $71 \%$ & 1202 & $75 \%$ & 1502 & $75 \%$ \\
\hline & 60 & 0.04798 & 658 & $50 \%$ & 846 & $54 \%$ & 1058 & $54 \%$ \\
\hline \multirow{3}{*}{$1.0 \%$} & 67 & 0.0562 & 953 & $71 \%$ & 1210 & $75 \%$ & 1513 & $75 \%$ \\
\hline & 65 & 0.0562 & 910 & $68 \%$ & 1157 & $72 \%$ & 1446 & $72 \%$ \\
\hline & 60 & 0.04798 & 638 & $49 \%$ & 819 & $52 \%$ & 1023 & $52 \%$ \\
\hline
\end{tabular}

*Discontinuous Working History

**Continuous Working History

***Continuous Working History (initial wage $25 \%$ higher)

To appreciate the magnitude of the effect of a dual labor market on the future pension benefits of the current young generations, let us consider the representative young (male) individual, who enjoys instead a continuous working career (case B). This individual enters the labor market at age 25 with a permanent job and the same monthly wage as in case A, that is, €800 (in 2001 prices), which however grows constantly over time, until reaching $€ 1600$ at the end of his working life, as shown at Figure 4.

It is worth noticing that, if compared to the previous individual (case A), his final wage is almost $€ 300$ higher, due to the progressive increase enjoyed during the permanent job tenure. Moreover, the representative individual with a continuous working career will also feature early career contributions and will hence have better prospects for his pension benefits. Table 3 (case B) shows his monthly pension benefits and pension replacement rates for three different retirement ages (60, 65 and 67 years) and three projections of the growth rate of the Italian GDP. Also in this case, the results show some variation, but pension benefits and replacement rate are consistently more generous than in the previous case. If the current representative young individual retires early (at 60 years), his monthly pension benefit will range between $€ 819$ and $€ 889$, depending on the average growth rate of the economy during his working life. These monthly benefits are almost $€ 200$ larger 
than the benefit received by the individual with a discontinuous working career - that is, almost a third of pension benefit higher! Retiring at 65 allows our second representative individual to enjoy a benefit of €1157-1273, depending on the realized economic growth - and thereby replacing around $75 \%$ of his wage income. Finally, by retiring at 67 years, he will obtain a pension benefit ranging between $€ 1210$ and $€ 1342$, with a replacement rate between $75 \%$ and $84 \%$.

Finally, we consider the situation of a male individual who enters the labor market with a permanent contract, and enjoys a 25\% higher initial wage (case C). His earning profile, as described at figure 5, widely differs from the previous cases, as this worker's wage starts from $€ 1000$ to reach almost $€ 2000$ by the end of his working career. Pension benefits differ accordingly. When retiring as early as at age 60, he still enjoys a pension benefit between $€ 1023$ and $€ 1112$, depending on the growth rate, although the replacement rates are around 55\%. Postponing the retirement age to 67 years would lead to sizable pension benefits, between $€ 1513$ and $€ 1677$.

Figure 5

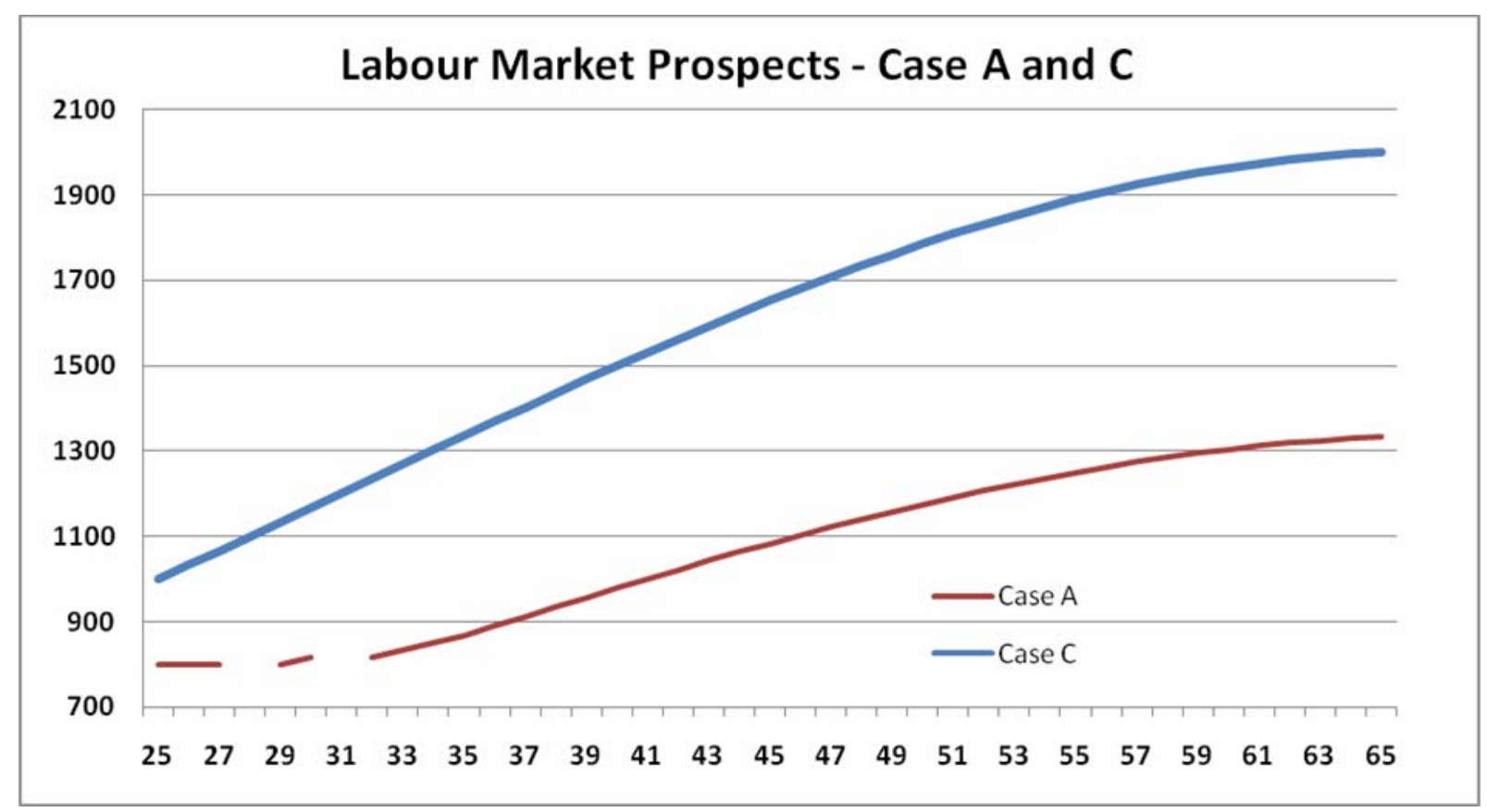

The dual labor market is known to have a strong, negative effect of the current young generation, these simulations suggest that it will continue to take its toll even in the long run, as pension benefits and replacement rates will be much lower than today. To see to what extent this negative impact can be imputed to the existence of an NDC system, which provides a tight link between (early) contributions and pension benefits, we simulated the pension benefits that two of our 
representative young individuals - respectively with a discontinuous (case A) and with a continuous working career (case B) - would have received with the old defined benefit (DB) system, which was in place in Italy prior to the Dini reform. Table 4 presents the results in terms of pension benefits and replacement rates for both individuals and two retirement ages - 60 and 65 years. Also in this case, the difference in pension benefits stemming from the different working careers are substantial. When retiring early (at 60 years), a current young with a continuous working history would have received €1117, amounting to €243 more a month than an individual with a discontinuous career, although the replacement rates would be comparable (72\% versus 67\%). The absolute difference in the pension benefits remains also when individuals retire later (at 65 years), but now current young affected by the dual labor market (case A) could nevertheless count on a pension benefits of $€ 1034$.

Table 4 Defined Benefit System

\begin{tabular}{|c|c|c|c|c|c|}
\cline { 2 - 3 } \multicolumn{1}{c|}{} & \multicolumn{4}{c|}{ Retributive System } \\
\cline { 2 - 3 } \multicolumn{1}{c|}{$\begin{array}{c}\text { Retirement } \\
\text { Age }\end{array}$} & $\begin{array}{c}\text { Replacement } \\
\text { Rates (2009) }\end{array}$ & $\begin{array}{c}\text { Monthly } \\
\text { Pension }\end{array}$ & & $\begin{array}{c}\text { Replacement } \\
\text { Rates (2009) }\end{array}$ & $\begin{array}{c}\text { Monthly } \\
\text { Pension }\end{array}$ \\
\hline 65 & $77 \%$ & 1034 & & $80 \%$ & 1274 \\
\hline 60 & $67 \%$ & 874 & & $72 \%$ & 1117 \\
\hline
\end{tabular}

These simple simulations thus suggest that the troubles lying ahead for the NDC system in Italy may not be due to some intrinsic feature of the system, but rather from its interaction with the dual labor market characteristic that is currently present in Italy. In fact, particularly in some positive instances, that is, for high economic growth and late retirement, the NDC system seems more sensitive to the lack of early career contributions than the previous defined benefit pension system, since pension benefits are simulated to drop more in the former system for the individuals with a discontinuous career. However, NDC systems are also better equipped to allow individuals to compensate the effects of these labor market distortions later in life. In fact, postponing retirement age is shown to be more beneficial in increasing pension benefits in the NDC system than in the previous DB scheme.

These simulations seem thus to support a double handed policy that tries to reduce the dualism of labor markets, for instance by allowing for graded employment security, as discussed in section 3.2 (see also Bentolila, Boeri, and Cahuc, 2010), while at the same time postponing the retirement age. 
In our simulations, when coupled with an average growth rate of the economy of $1.5 \%$, this strategy would have led to a monthly pension benefit of almost $€ 1350$ for our representative, middleeducated male individual.

\subsection{Simulating the Swedish labor market and pension system}

In this section, we replicate our previous simulations for the Swedish pension system and labor market. We consider two representative young males, with upper secondary education, and respectively a discontinuous (case A) and a continuous (case B) working career, but the same entry wage. Their wage profile is calculated using data from the 1997 and 2001 waves of the European Commission Household Panel. We use the same labor market prospects as in section 4.1 for Italy. Our representative individual with a discontinuous career enters the labor market at age 25 with a temporary job that holds until age 28; he is unemployed from 28 to 29, when he obtains a fixed term job. At 32, he is unemployed again for a year, then holds a fixed term job for two years, and finally a permanent job until retirement. However, the Swedish representative young individual enters the labor market with a higher monthly wage, namely, almost €900 (in 2001 prices). Again, this wage remains relatively flat until age 35; then our young male obtains a permanent job, and his wage growth becomes steeper, till reaching more than $€ 1700$ at the end of his working life ${ }^{6}$, as shown in Figure 6.

Figure 6

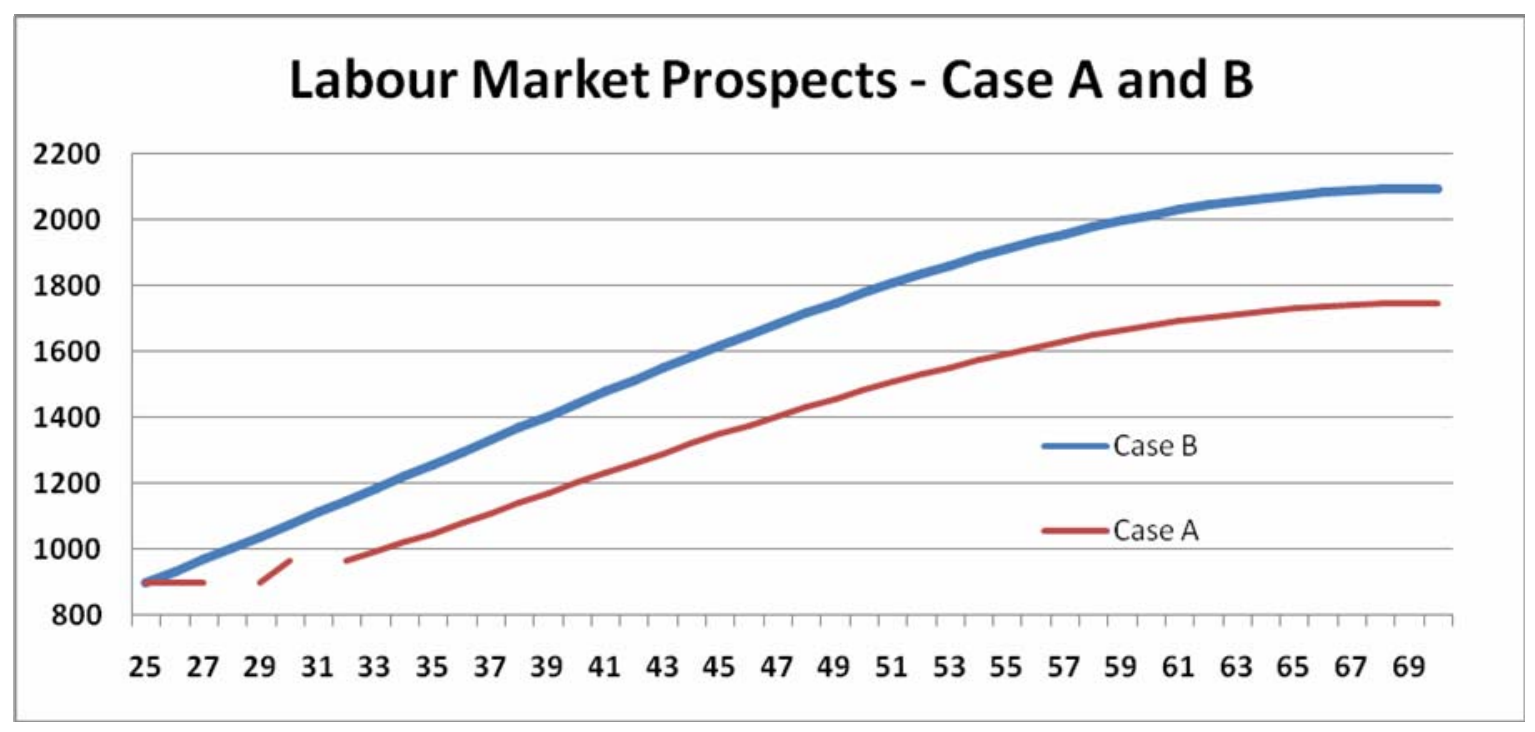

${ }^{6}$ Here, we consider a retirement age up to 70 years. 
Table 5 summarizes the pension benefits of this individual with a discontinuous working career, who cannot enjoy the beneficial compounding capitalization on the early-in-working-life contributions. The monthly pension benefit and the pension replacement rate are shown for three different retirement ages (65, 67 and 70 years) and two GDP growth rates (1.5\% and 2\%). Again, the range of variation is large. If the current representative young individual will retire early - by Swedish standards - that is, at 65 years, his monthly pension benefit will range between $€ 811$ and $€ 957$, depending on the average growth rate of the economy during his working life, thus providing a replacement rate around $46 \%$. Retiring later clearly increases the amount of the pension benefits, which becomes as a high as $€ 1506$, if the individual retires at 70 years, and the average growth rate of economy has been $2 \%$.

Table 5: Case A and B

\begin{tabular}{|c|c|c|c|c|c|c|}
\cline { 3 - 6 } \multicolumn{2}{c|}{} & \multicolumn{2}{c|}{ Case A } & \multicolumn{2}{c|}{ Case B } \\
\hline $\begin{array}{c}\text { Growth } \\
\text { Rate } \\
(\mathbf{g})\end{array}$ & $\begin{array}{c}\text { Retirement } \\
\text { Age }\end{array}$ & $\begin{array}{c}\text { Transformation } \\
\text { Coefficients } \\
\mathbf{( 2 0 0 9 )}\end{array}$ & $\begin{array}{c}\text { Monthly } \\
\text { Pension }\end{array}$ & $\begin{array}{c}\text { Replacement } \\
\text { Rate }\end{array}$ & $\begin{array}{c}\text { Monthly } \\
\text { Pension }\end{array}$ & $\begin{array}{c}\text { Replacement } \\
\text { Rate }\end{array}$ \\
\hline \multirow{3}{*}{$\mathbf{1 . 5 \%}$} & $\mathbf{6 5}$ & $\mathbf{0 . 0 6 2 1}$ & 811 & $47 \%$ & 1005 & $48 \%$ \\
\cline { 2 - 7 } & $\mathbf{6 7}$ & $\mathbf{0 . 0 6 7 8}$ & 964 & $55 \%$ & 1192 & $57 \%$ \\
\cline { 2 - 7 } & $\mathbf{7 0}$ & $\mathbf{0 . 0 7 8 4}$ & 1249 & $72 \%$ & 1541 & $74 \%$ \\
\hline \multirow{3}{*}{$\mathbf{2 . 0 \%}$} & $\mathbf{6 5}$ & $\mathbf{0 . 0 6 2 1}$ & 957 & $46 \%$ & 1206 & $48 \%$ \\
\cline { 2 - 7 } & $\mathbf{6 7}$ & $\mathbf{0 . 0 6 7 8}$ & 1147 & $55 \%$ & 1444 & $56 \%$ \\
\cline { 2 - 7 } & $\mathbf{7 0}$ & $\mathbf{0 . 0 7 8 4}$ & 1506 & $71 \%$ & 1892 & $72 \%$ \\
\hline
\end{tabular}

To understand the relevance of the effect of a dual labor market we now simulate the future pension benefits for the representative young (male) individual, with a continuous working career (case B). This individual still enters the labor market at age 25, but with a permanent job and a higher monthly wage (around €900 in 2001 prices), which moreover increases constantly over time, until reaching $€ 2100$ at the end of his working life, as shown at Figure 6. This represents a wage gap of almost $€ 400$ at the end of the working life, entirely driven by the early experience in the labor market. Table 5 displays the associated monthly pension benefits and pension replacement rates for three different retirement ages (65, 67 and 70 years) and two GDP growth rates. Clearly, pension benefits, albeit not replacement rates, are consistently more generous than in the previous case. If the current representative young individual retires early (at 65 years), his monthly pension benefit will range between $€ 1005$ and $€ 1206$, thereby being around $€ 200$ larger than the corresponding benefits for the individual with a discontinuous working career. Retiring at 70 years busts the pension benefits to $€ 1541-€ 1892$ and the replacement rate to $72 \%-74 \%$. 
Even in Sweden, the dual labor market has thus the potentials to have a strong negative effect on the pension benefits of the current young generations. However, the reduction in pension benefits driven by (the same) dual labor market seems to be less of a concern in Sweden. This is because pension benefits drop by less, albeit on average still by a sizable $25 \%$, due to negative early labor market experiences, but mainly because of the extremely large bust that postponing retirement seems to have on the pension benefits. For instance, an individual with a discontinuous working career retiring at age 70 would obtain a larger pension benefit ( $€ 1251$ or $€ 1509$, depending on the average GDP growth rate) than an individual with a continuous working career retiring at age 67 (€1192 or $€ 1444)$.

\section{Concluding remarks}

The introduction of NDC systems in the 90s has been often advocated as the appropriate reform to achieve several crucial objectives, such as the long run financial sustainability of these PAYG pension systems and the reduction of the distortions introduced in the labor market. Ten years after their introduction, an evaluation of their effects is overall positive. Yet, some aspects of the implementation of these systems raise some concerns. For instance, the indexation of pension benefits adopted in Italy gives rise to a "vintage pensions" problem, which may be further exacerbate by the aging electorate. Analogously, the indexation to wages (rather than the to wage bill) in Sweden have proven problematic during big recessions. Careful consideration should be made to adopting an indexation mechanism based on deviations in the growth of the wage bill (the contribution base) from the potential growth rate of the economy. This indexation scheme would also have the advantage of explicitly linking the fate of pensioners to that of current workers, reducing the conflict of interests between (young) workers and pensioners and increasing the support to growth-friendly policies.

In pension reforms indeed problems typically emerge in the political arena. NDC reforms may not prove different from these past experiences, particularly in the near future, when the application of the NDC rules in countries that have adopted long transition periods, such as Italy and Poland, will lead to the retrenchment of pension benefits. This may provoke the political opposition of future generations of elderly having to retire on low pensions. Although NDC have often be designed in order for their functioning to be isolated from political interference, some features of NDC schemes, 
such as the conversion coefficients, may still be open to manipulations by politicians to increase the pension generosity. Dual track reform may also be further used to increase the burden on the young generations.

This paper has focused on a new challenge to the NDC systems, which may come from the current working of the labor market in many European countries. NDC systems provide a tight link between contributions and pension benefits. Moreover, due to the compounded effects of the interest rates, early contributions have particular relevance for the final accumulated pension wealth, and thus for the pension benefits. Unfortunately, in dual labor markets, young individuals experience discontinuous working careers, and thus typically fail to accumulate pension contributions early in their working lives. Our simulations suggest that this translates into low future pension benefits, and in the need to postpone retirement. Young individuals, who are off a bad start in the labor market, are also up to a bad finish in the pension system.

A possible solution to this new problem is to adopt a double ended policy. To help the individuals early in their working career, a contract that features a graded employment security could be introduced (see also Bentolila, Boeri, and Cahuc, 2010) to reduce the dualism of labor markets. But later in their working lives, individuals have to be ready to postponing retirement age. 


\section{Bibliography}

Auerbach, A.J. and Lee, R. (2009) "Welfare and Generational Equity in Sustainable Unfunded Pension Systems," NBER Working Papers 14682, National Bureau of Economic Research, Inc.

Barr, N. and P. Diamond (2008) Reforming pensions: Principles and Policy Choices. Oxford University Press.

Bentolila, S., T. Boeri, and P. Cahuc (2010) “Ending the scourge of dual labour markets in Europe”, Vox, 12/7/2010. Also in LaVoce and Nada es Gratis.

Boeri, T., (2010) “Institutional Reforms and Dualism in European Labor Markets” In Ashenfelter, O. and Card, D. (eds.), Handbook of Labor Economics Volume, 2010

Börsch-Supan, A. and C.B. Wilke (2006) “The German Public Pension System: How It Will Become an NDC System Look-Alike” In Pension Reform: Issues and Prospects for Non-Defined Contribution (NDC) Schemes, ed. R. Holzmann and E. Palmer, Washington, DC: World Bank.

Brugiavini, A. and Galasso, V. (2004) "The social security reform process in Italy: where do we stand?," Journal of Pension Economics and Finance, Cambridge University Press, Vol. 3(02), pp. 165-195.

Diamond, P. A. (2004) “Social Security.” American Economic Review 94(1), pp. 1-24.

Franco, D. (2002) “Italy: a never-ending pension reform”, in Feldstein, M., and H. Siebert (eds.), Social security pension reform in Europe. NBER and The Chicago University Press, Chicago and London.

Galasso V. (2008) “Postponing retirement: the political push of aging”, Journal of Public Economics, Vol. 92(10-11), pp. 2157-2169.

Galasso, V. (2006) The Political Future of Social Security in Aging Societies, MIT Press Books, The MIT Press. 
Gronchi, S. (1998) "La sostenibilità delle nuove forme previdenziali ovvero il sistema pensionistico tra riforme fatte e da fare”, Economia Politica, Vol. XV, pp. 295 -315.

Gronchi, S., and R. Aprile (1998) “The 1995 pension reform: sustainability and indexation”, Labor, Vol. 12, pp. $67-100$.

Gronchi S. and Nisticò S. (2006) "Implementing the NDC Theoretical Model: A Comparison of Italy and Sweden”, in R. Holzmann, and E. Palmer (eds), Pension Reforms: Issues and prospects for Non-Financial Defined Contribution (NDC) Schemes, The World Bank.

Holtzmann R. and Palmer E. (Eds.) (2005) Non-Financial Defined Contribution (NDC) Pension Schemes: Concept, Issues, Implementation, Prospects. The World Bank, Washington D.C.

Konberg, B., E. Palmer, and A. Sunden (2006) “The NDC Reform in Sweden: The 1994 Legislation to the Present” In Pension Reform: Issues and Prospects for Non-Defined Contribution (NDC) Schemes, ed. R. Holzmann and E. Palmer, Washington, DC: The World Bank.

Legros, F., (2006) “Notional Defined Contribution: A Comparison of the French and German Point System”, in R. Holzmann, and E. Palmer (eds), Pension Reforms: Issues and prospects for NonFinancial Defined Contribution (NDC) Schemes, The World Bank.

Mulligan, C. B. and X. Sala-i-Martin (1999) “Gerontocracy, Retirement, and Social Security”, NBER Working Paper No. W7117.

Palmer, E. (2006) “What is NDC”, in R.Holzmann, and .E.Palmer (eds), Pension Reforms: Issues and prospects for Non-Financial Defined Contribution (NDC) Schemes, The World Bank. In Pension Reform: Issues and Prospects for Non-Defined Contribution (NDC) Schemes, ed. R. Holzmann and E. Palmer, Washington, DC: The World Bank.

Palmer, E. (2000) “The Swedish Pension Reform Model: Framework and Issues”, The World Bank Social Protection Discussion Paper 12. 
Tapia, W. and J. Yermo (2007) "Implications of behavioral economics for mandatory individual account pension systems”, Working paper on Insurance and Private Pensions n. 11, OECD: Paris.

The World Bank (1994) World Development Report 1994: Infrastructure for Development, Washington, DC: The World Bank. 